\title{
The Examination of Exercise Addiction Levels of University Students Studying in Health Field
}

\author{
Ergün Çakir \\ Correspondence: Ergün Çakir, School of Physical Education and Sports, Kafkas University, Kars / Turkey.
}

Received: January 9, 2019

doi:10.11114/jets.v7i3.4096

\author{
Accepted: February 17, 2019 \\ Online Published: February 26, 2019 \\ URL: https://doi.org/10.11114/jets.v7i3.4096
}

\begin{abstract}
The aim of this study was to determine the exercise addiction levels of Van Yüzüncü Y1l University Vocational School of Health Services and Health Vocational School Students. The population of the study consisted of the students studying in Van Yüzüncü Y1l University Health Services Vocational School and Health Vocational School. The Exercise Addiction Scale (ESS), eveloped by Tekkurşun Demir et al. (2018) was applied to the participants. Significant differences were found in comparisons (a) between age and over-focussing and change of emotion, (b) gender and postponement of individual-social needs and conflict, (c) regular sporting and conflict, (d) tolerance development and passion, (e) sporting frequency and over-focussing and change of emotion, $(\mathrm{p}<0.05)$. As a result, it was determined that age, sex, the frequency of doing sports and regular sporting affected exercise addiction.
\end{abstract}

Keywords: exercise, exercise addiction, physical activity

\section{Introduction}

\section{The importance of researching}

The importance of researching these needs was to determine the differences in exercise addiction of individuals participating in exercises.

\section{Literature Review:}

Exercise addiction; is defined as the exercise routine to control the individual, the duration and duration of the exercise to increase the frequency and severity of the exercise, the ability to take time away from exercising with family and friends, to exercise instead of participating in social activities and to rehabilitate the individual's life within the framework of exercise habits. It manifests itself with physiological symptoms (tolerance, avoidance) or psychological symptoms (depression, tension) in the exercise process (Zmijewski and Howard 2000; Kagan and Squires, 1985).

The chief functions of exercise are to prevent or slow down the psychological and social disorders caused lifestyle by saving the individual from sedentary life, to increase the physiological capacity which is the basis of body health and to protect health as much as possible (Çakır and Şenel, 2017).

Regular physical activity prevents premature aging and supports maintaining good quality of life. Forty to fifty minutes of walking a day or in the form of low-paced jogging provides many benefits. For instance, this exercise may reduce coronary heart disease by $50 \%$, and the risk of hypertension, diabetes and colon cancer by $30 \%$ (Zorba, 1999).

The results of many studies indicate that exercise contributes to physical and psychological health (Bouchard et al., 1994,). Besides the positive effects of exercise, exercise also has negative effects (Szabo, 1998; Johansson and Gotestam, 2004). Exercise addiction is the most important concept to be dealt with while explaining the negative results of exercise. Exercise addiction was first described by Veale (1995). Researchers define exercise addiction as the degree and frequency of participation in the exercise program. In other words, they define it as an event in which excessive participation to an exercise becomes uncontrollable or leisure activity. In addition, exercise addiction includes physiological (tolerance development) or psychological symptoms (anxiety, depression). Exercise addiction, in particular, expresses the desire to exercise with a strong emotion in every leisure time of a person (Adams and Kirkby 2002). This can be defined by the percentage rate. For example, the rate of those who participate ten of twenty sessions is 50\% (Willis and Campbell, 1991). Those who participate less than $10 \%$ are classified as those who left early, those who participate between $10 \%$ and $49 \%$ as those who did not show dependency, and those who participate $50 \%$ or more as those who showed addiction (Gale et al., 1984). It is possible to classify exercise addiction into four stages. While having fun is in the first 
stage, the beginning of the risk appears in the second stage and the planning of life according to exercise in the third stage and finally exercise becomes an extremely important part of the life in the fourth stage (Uzbay, 1996).

The preparation and implementation of a schedule or program affect exercise addiction. Time and space availability (Wankel, 1985), physical characteristics of the facility, characteristics of the leader, intensity of the program, entertainment factor, the effect of social and psychological factors and social support play an important role in exercise addiction (Willis and Campbell, 1991).

\section{Material and Method}

\section{Research model}

The research was conducted using scanning method, an approach that aims to define a situation that exists in the past or still present (Arlı and Nazik, 2001), from quantitative research models.

\section{Research group}

The population of the research consisted of Van Yüzüncü Yıl University Health Services Vocational School and Health Vocational School students. The sample group consisted of 140 students (103 females, 37 males,) who studied nursing, midwifery, first emergency aid, medical documentation, radiotherapy, disabled care and rehabilitation, anaesthesia and aged care.

\section{Data collection tool}

Exercise addiction Scale developed by Tekkurşun Demir et al. (2018) was used as the data collection tool. The Exercise addiction Scale consists of 17 items and three sub-dimensions. Articles 11,10, 9, 21,16, 33, 28 measure the dimension of the Over-focussing and Emotion Change whereas articles 30,32, 31, 13, 15, 17 measure the Postponement and Conflict dimension of Individual-Social Needs, and articles 3, 1, 2 and 19 measure the Tolerance Development and Passion dimension. In this context, the scale is arranged in 5-point Likert-type format.

\section{Statistical analysis}

SPSS 23 package program was used to analyse the data. It was examined whether the skewness and kurtosis values were between \pm 1 before deciding the analyses to be made. In this context, parametric tests were applied to the data. Frequency, Percentage, Average, $\mathrm{t}$ test, Pearson Moment Collation Number of Floors, One-Way Variance Analysis (ANOVA) statistics were used.

\section{Results}

Table 1. The relationship between the age variable and the level of exercise addiction

\begin{tabular}{|c|c|c|c|c|c|c|c|}
\hline Variables & Age & $\begin{array}{l}\text { Excessive Focus } \\
\text { and Emotion } \\
\text { Change }\end{array}$ & $\begin{array}{l}\text { Postponement } \\
\text { Individual-Social } \\
\text { and Conflict }\end{array}$ & $\begin{array}{r}\text { of } \\
\text { Needs }\end{array}$ & $\begin{array}{l}\text { Tolerance } \\
\text { Development and } \\
\text { Passion }\end{array}$ & $\mathrm{x}$ & ss \\
\hline Age & 1 & $186^{*}$ &, 146 & &, 095 & 21,35 & 2,57 \\
\hline $\begin{array}{l}\text { Excessive Focus and } \\
\text { Emotion Change }\end{array}$ &, $186^{*}$ & 1 &, $266 * *$ & &, $442 * *$ & 21,25 & 5,69 \\
\hline $\begin{array}{lr}\text { Postponement } & \text { of } \\
\text { Individual-Social } & \text { Needs } \\
\text { and Conflict }\end{array}$ & ,146 &, $226 * *$ & 1 & &, $599 * *$ & 14,05 & 4,98 \\
\hline $\begin{array}{l}\text { Tolerance Development } \\
\text { and Passion }\end{array}$ & ,095 &, $442 * *$ &, $599 * *$ & & 1 & 9,77 & 4,01 \\
\hline
\end{tabular}

The significance in the relation between age and over-focusing and emotion change was determined as $\mathrm{p}<0.05$ while it was $\mathrm{p}<0.01$ in the relationship between postponement of individual-social needs and conflict and emotion change and it was found to be $\mathrm{P}<0.01$ in the relationship between Tolerance Development and Passion Focusing and Emotion Change.

Table 2. Independent Group t Test Results of Gender Variables

\begin{tabular}{|c|c|c|c|c|c|c|c|}
\hline Variables & Gender & $\mathrm{N}$ & $\overline{\boldsymbol{x}}$ & Ss & $\mathrm{df}$ & $\mathrm{t}$ & $\mathrm{p}$ \\
\hline \multirow{2}{*}{ Excessive Focus and Emotion Change } & Women & 103 & 20,83 & 5,58 & \multirow{2}{*}{138} & \multirow{2}{*}{$-1,44$} & \multirow[t]{2}{*}{15} \\
\hline & Men & 37 & 22,40 & 5,89 & & & \\
\hline \multirow{2}{*}{ Postponement of Individual-Social Needs and Conflict } & Women & 103 & 13,44 & 4,45 & \multirow{2}{*}{138} & \multirow{2}{*}{$-2,43$} & \multirow[t]{2}{*}{, $01 *$} \\
\hline & Men & 37 & 15,72 & 5,99 & & & \\
\hline \multirow{2}{*}{ Tolerance Development and Passion } & Women & 103 & 9,11 & 3,73 & \multirow{2}{*}{138} & \multirow{2}{*}{$-3,37$} & \multirow{2}{*}{, 00} \\
\hline & Men & 37 & 11,62 & 4,21 & & & \\
\hline
\end{tabular}

$* \mathrm{p}<0,05$ 
When the Independent Group t Test Results of Gender Variation were examined, there was significant difference in the relationship between Postponement of Individual-Social Needs and Conflict $(\mathrm{P}<0.05)$.

Table 3. $t$ Test Results of Independent Group with Regular Sport Making Variables.

\begin{tabular}{|c|c|c|c|c|c|c|c|}
\hline Variables & Regular training & $\mathrm{N}$ & $\overline{\mathrm{x}}$ & Ss & df & $\mathrm{t}$ & $\mathrm{p}$ \\
\hline \multirow{2}{*}{ Excessive Focus and Emotion Change } & Yes & 45 & 23,28 & 5,90 & \multirow{2}{*}{137} & \multirow{2}{*}{3,088} & \multirow{2}{*}{, $00^{*}$} \\
\hline & No & 94 & 20,20 & 5,32 & & & \\
\hline \multirow{2}{*}{ Postponement of Individual-Social Needs and Conflict } & Yes & 45 & 16,17 & 5,56 & \multirow{2}{*}{137} & \multirow{2}{*}{3,761} & \multirow{2}{*}{, $00^{*}$} \\
\hline & No & 94 & 12,94 & 4,29 & & & \\
\hline \multirow{2}{*}{ Tolerance Development and Passion } & Yes & 45 & 11,88 & 3,71 & \multirow{2}{*}{137} & \multirow{2}{*}{4,851} & \multirow{2}{*}{, $00^{*}$} \\
\hline & No & 94 & 8,67 & 3,63 & & & \\
\hline
\end{tabular}

When the Independent Group t Test Results with Regular Sport Making Variable were examined, difference between Excessive Focus and Emotion Change, Postponement of Individual-Social Needs and Conflict, Tolerance Development and Passion were significant $(\mathrm{p}<0.05)$.

Table 4. ANOVA Results according to the frequency of making sports

\begin{tabular}{|c|c|c|c|c|c|c|c|c|c|}
\hline & $\begin{array}{l}\text { Frequency of } \\
\text { making sports }\end{array}$ & $\mathrm{N}$ & $\overline{\mathrm{x}}$ & Variance & $\begin{array}{l}\text { Sum of } \\
\text { Squares }\end{array}$ & $\begin{array}{l}\text { Mean } \\
\text { Square }\end{array}$ & $\mathrm{F}$ & $\mathrm{p}$ & $\begin{array}{l}\text { Significant } \\
\text { Difference }\end{array}$ \\
\hline \multirow{4}{*}{$\begin{array}{l}\text { Excessive Focus and } \\
\text { Emotion Change }\end{array}$} & Never do & 80 & 20,1625 & \multirow{4}{*}{$\begin{array}{l}\text { Between } \\
\text { Groups } \\
\text { In-group }\end{array}$} & \multirow{4}{*}{$\begin{array}{l}350,719 \\
4151,531\end{array}$} & \multirow{4}{*}{$\begin{array}{l}87,680 \\
30,752\end{array}$} & \multirow{4}{*}{2,851} & \multirow{4}{*}{, $02 *$} & \multirow{4}{*}{$\begin{array}{l}\text { Twice a week } \\
\text { - Never do }\end{array}$} \\
\hline & Once a week & 33 & 21,4545 & & & & & & \\
\hline & Twice a week & 13 & 23,8462 & & & & & & \\
\hline & $\begin{array}{l}\text { 3or more per } \\
\text { week }\end{array}$ & 13 & 24,3077 & & & & & & \\
\hline \multirow{4}{*}{$\begin{array}{l}\text { Postponement } \\
\text { Individual-Social Needs } \\
\text { and Conflict }\end{array}$} & Never do & 80 & 13,0750 & \multirow{4}{*}{$\begin{array}{l}\text { Between } \\
\text { Groups } \\
\text { In-group }\end{array}$} & \multirow{4}{*}{$\begin{array}{l}255,347 \\
3203,303\end{array}$} & \multirow{4}{*}{$\begin{array}{l}63,837 \\
23,728\end{array}$} & \multirow{4}{*}{2,690} & \multirow{4}{*}{, $03^{*}$} & \multirow{4}{*}{$\begin{array}{l}\text { Twice a week } \\
- \\
\text { Never do }\end{array}$} \\
\hline & Once a week & 33 & 14,5758 & & & & & & \\
\hline & Twice a week & 13 & 16,1538 & & & & & & \\
\hline & $\begin{array}{l}\text { 3or more per } \\
\text { week }\end{array}$ & 13 & 16,0000 & & & & & & \\
\hline \multirow{4}{*}{$\begin{array}{l}\text { Tolerance Development } \\
\text { and Passion }\end{array}$} & Never do & 80 & 8,6875 & \multirow{4}{*}{$\begin{array}{l}\text { Between } \\
\text { Groups } \\
\text { In-group }\end{array}$} & \multirow{4}{*}{$\begin{array}{l}342,818 \\
1893,318\end{array}$} & \multirow{4}{*}{$\begin{array}{l}85,704 \\
14,025\end{array}$} & \multirow{4}{*}{6,111} & \multirow{4}{*}{, $00^{*}$} & \multirow{4}{*}{$\begin{array}{l}\text { Twice a week } \\
- \\
\text { Never do }\end{array}$} \\
\hline & Once a week & 33 & 10,2121 & & & & & & \\
\hline & Twice a week & 13 & 12,2308 & & & & & & \\
\hline & $\begin{array}{l}\text { 3ormore per } \\
\text { week }\end{array}$ & 13 & 12,2308 & & & & & & \\
\hline
\end{tabular}

$* \mathrm{p}<0,05$

The results of variance analysis according to the frequency of making sports proved to be statistically significant $\mathrm{p}$ $<0.05$ in terms of the answers given to the questions on excessive focus and emotion change, postponement of individual-social needs and Conflict, Tolerance Development and Passion.

\section{Discussion and Conclusion}

It has been stated by many scientific studies (Davis et al. 1993; Gonul, T. D. at al., 2018; Hausenblas and Fallon, 2002; Kaya et al., 2018; Demir et al., 2018; Demir et al., 2017; Vardar et al., 2012; Zırhlıoğlu, 2011; Furst and Germone, 1993) that the sport has a number of benefits. However, as the excess of all things can have negative sides, it can be argued that the excesses of the sport can be harmful. In this study, it is aimed to evaluate the sport in terms of addiction. When the studies related to the subject are examined.

The relationship between age and excessive focus and change of emotion was determined significant as $\mathrm{p}<0.05$, similarly, the relationship between postponement of individual-social needs and conflict and excessive focus and change of emotion was significant as $\mathrm{p}<0.01$, in addition, the relationship between tolerance development and excessive focus and emotion change in passion was significant $\mathrm{p}<0.01$ (table 1 ).

When independent group $t$ test results were examined in terms of gender variable, the difference between postponement of individual-social needs and conflict were significant, $\mathrm{p}<0.05$ (table 2).

Regarding the independent group $t$ test results with regular sporting variable, the significance in the difference between excessive focus and emotion change, postponement of individual-social needs and conflict, tolerance development and passion was negative $\mathrm{p}<0.05$ (table 3 ).

Given the responses such as doing sports twice a week and no sporting to the questions for excessive focus and change of emotion, postponement of individual-social needs conflict, tolerance development and passion, the results of variance analysis according to the frequency of sports showed statistical significance $\mathrm{p}(<0,05)$. When compared to the results of 
the present study, there are studies in the literature that reached similar (Costa et al., 2013; Sadiq, 2018) and different results (Cicioğlu et al, 2019).

In this study conducted on the individuals doing sports in fitness centres, the rate of exercise addiction symptoms was found to be $1.6 \%$ and the risk of addiction was $84.1 \%(\mathrm{Uz}, 2015)$. There are many studies in the literature showing that the risk of exercise addiction is high in the individuals who are university students and do sport regularly (Cicioğlu et al, 2019; Hausenblas and Fallon, 2002; Tekkurşun Demir and Türkeli, 2019; Vardar et al., 2012; Zırhlığlu, 2011; Gonul, T.D at al., 2018). In another study found that participants who participated in the study did not have a statistically significant difference between the genders, age, exercise age, marital status, education level, sports branch, job, weekly training day, the daily exercise duration, physical apperance and cause of exercise compared to the total exercise addiction score ( $>0,05)$.

In a similar study, Davis et al. (1993) found that there was no significant difference in BMI between men and women, but a high positive correlation between exercise weight (Devis et al., 1993). Furst and Germone (1993) found no difference between genders in terms of exercise addiction (Furst and Germone, 1993). In another study Pierce et al (1997) found that females had a higher score of exercise addictionthan males. However, there was no gender difference in exercise frequency in the same study (Pierce et al., 1997).

In the studies examined, it is shown that the reasons for exercise of healthy individuals are the desire to stay healthy, to get rid of excess weight, to receive approval from the opposite sex and these individuals prefer exercises such as jogging, fitness, football, bodybuilding and swimming (Zırhlıoğlu, 2011; Bavli et al., 2011; Uz, 2015; Mor et al., 2017; Çakir et al., 2016; Kaya et al., 2018; Demir et al., 2018; Demir et al., 2017). In another study, found that regular training can be effective to appear the exercise addiction (Koob, 1992; Morgan, 1979; Tekkurşun Demir and Türkeli, 2019; Sadıq, 2018; Orford, 1985).

As a result, it was determined that age, sex, the frequency of doing sports and regular sporting affected exercise addiction ( $\mathrm{p}<0.05)$. Thus, it can be said that regular exercise can be effective in exercise addiction.

\section{References}

Adams, J., \& Kirkby, R. J. (2002). Excessive Exercise as an Addiction: A Review. Addiction Research and Theory, 10, 415-437.

Arlı, M., \& Nazik, M. H. (2001). Bilimsel araştırmaya giriş, Gazi Kitapevi, Ankara

Bavlı, Ö., Kozanoğlu, M. E., \& Doğanay, A. (2011). Investigation the Effects of Participation Regular Exercise on Exercise Dependence. Selcuk University Pysical Education and Sport Journal of Science, 13(2), 150-153.

Bouchard, C., Shephard, R. J., \& Stephens, T. (1994). Physical Activity, Fitness and Health: International Proceedings and Consensus Statement. Champaign, IL, Human Kinetics.

Çakır, E., \& Şenel, Ö. (2017). Effect of Cold Water İmmersıon on Performance. European Journal of Physical Education and Sport Science.

Çakir, E., Yüksek, S., Asma, B., \& Arslanoglu, E. (2016). Effects of Different Environment Temperatures on Some Motor Characteristics and Muscle Strength. International Journal of Environmental and Science Education, 11(10), 3985-3993.

Cicioğlu, H. İ., Tekkurşun Demir, G., Bulgay, C., \& Çetin, E. (2019). Examining Exercise Addictions Levels Of The Elite Level Athletes And Students Of Sports Sciences Faculty. Journal of Dependence, 20(1), 1-5.

Costa, S., Hausenblas, H., Oliva, P, Cuzzocrea, F., \& Larcan, R. (2013). The Role Of Age, Gender, Mood States And Exercise Frequency On Exercise Dependence. Journal of Behavioral Addictions, 2(4), 216-223. https://doi.org/10.1556/JBA.2.2013.014

Davis, C., Brewer, H., \& Ratusny, D. (1993). Behavioral frequency and psychological commitment: Necessary concepts in the study of excessive exercising. Journal of Behavioral Medicine, 16, 611-628. https://doi.org/10.1007/BF00844722

Demir, G. T., \& Cicioğlu, H. İ. (2018). Motivation Scale For Participation In Physical Activity (Msppa): A Study Of Validity And Reliability, Journal Of Human Sciences, 15(4), 2479-2492. https://doi.org/10.14687/jhs.v15i4.5585

Demir, G. T., Cicioğlu, H. İ., İlhan, E. L., \& Arslan, Ö. (2017). The Classroom Student Teachers' Value Reflection Towards Physical Education Lesson, International Journal Of Sport, Exercise \& Training Sciences, 3(4), 120-128. https://doi.org/10.18826/useeabd.319676

Demir, G. T., Hazar, Z., \& Cicioğlu, H. İ. (2018). Exercise Addiction Scale (EAS): A Study of Validity and Reliability. Kastamonu Education Journal, 26(3), 865-874. https://doi.org/10.24106/kefdergi.413383

Furst, D. M., \& Germone, K. (1993). Negative addiction in male and female runners and exercise. Perceptual and Motor Skills, 77, 192-194. https://doi.org/10.2466/pms.1993.77.1.192 
Gale, J. B., Eckhoff, W. T., Mogel, S. F., \& Rodnick, J. E. (1984). Factors related to adherence to an exercise program for healthy adults. Med Sci Sports Exerc., 16, 544-549. https://doi.org/10.1249/00005768-198412000-00004

Gönül, T. D., Levent, İ. E., İbrahim, C. H., \& Sevinç, N. (2018). Examination Of The Values Gained By High School Students Through Physical Education And Sport Lesson. Ovidius University Annals, Series Physical Education \& Sport/Science, Movement \& Health, 18.

Hausenblas, H. A., \& Fallon, E. A. (2002) Relationship among body image, exercise behavior, and exercise dependence symptoms, Inc. Int J Eat Disord., 32, 179-185. https://doi.org/10.1002/eat.10071

Johansson, A., \& Gotestam, K. G. (2004). Problems with computer games without monetary reward: similarity to pathological gambling. Psychol. Rep., 95, 641-650. https://doi.org/10.2466/pr0.95.2.641-650

Kagan, D. M., \& Squires, R. L. (1985). Addictive Aspects of Physical Exercise. Journal of Sport Medicine, 25, 227-237

Kaya, Ö., Cicicoğlu, H. İ., \& Demir, G. T. (2018). The Attitudes Of University Students Towards Sports: Attitude And Metaphorical Perception. European Journal Of Physical Education And Sport Science.

Koob, F. G. (1992). Drugs of abuse: anatomy, pharmacology and function of reward pathways. Trends Pharmacol Science, 13, 177-184. https://doi.org/10.1016/0165-6147(92)90060-J

Mor, A., İpekoğlu, G., Arslanoglu, C., Acar, K., \& Arslanoglu, E. (2017). The Effects of Electrostimulation and Core Exercises on Recovery After High-Intensity Exercise. International Journal of Applied Exercise Physiology, 6(4), 46-53. https://doi.org/10.22631/ijaep.v6i4.178

Morgan, W. P. (1979). Negative addiction in runners. The Physician and Sports Medicine, 7, 57-77. https://doi.org/10.1080/00913847.1979.11948436

Orford, J. (1985). Excessive appetites: A psychological view of addictions. Chichester: Wiley.

Pierce, E. F., Rohaly, K. A., \& Fritchley, B. (1997). Sex differences of exercise dependence for men and women in a marathon road race. Perceptual and Motor Skills, 84, 991-994. https://doi.org/10.2466/pms.1997.84.3.991

Sadiq, B. J., \& Orhan, S. (2018). Investigation of The Exercıse Dependence of Athlets' Kıck Boxıng, Taekwondo And Muay Tha1. Firat University Institute of Health Sciences Department of Physical Education and Sports. Elazığ

Szabo, A. (1998). Studying the psychological impact of exercise deprivation: Are experimental studies hopeless? Journal of Sport Behavior, 21, 139-47.

Tekkurşun Demir, G., \& Türkeli, A. (2019). Examination Of Exercise Addiction And Mental Strength Levels Of Students Of Sport Sciences Faculty. Journal of Sport Sciences Researches. 4(1), 9-24.

Uz, İ., \& Bavlı, Ö. (2015). Fitness merkezlerine düzenli katılan bireylerde egzersiz bağımlılığının incelenmesi. Çanakkale Onsekiz Mart Üniversitesi Sağlık Bilimleri Enstitüsü. Beden Eğitimi ve Spor Öğretmenliği Anabilim Dalı Yüksek Lisans Tezi. Çanakkale

Uzbay, İ. T. (1996). Alkol, Farmakolojik özellikleri ve alkol bağımlılığının nörofarmakolojik yönü. Ege Psikiyatri Sürekli Yayınları (Alkol kullanım bozuklukları ve tedavisi), 1(2), 227-254.

Vardar, E. (2012).Exercise Dependence Trakya University Faculty of Medicine Department of Psychiatry ,Edirne Arsiv Kaynak Tarama Dergisi (Archives Medical Review Journal), 21(3), 163-173

Veale, D. (1995). Does primary exercise dependence really exist? In: Exercise Addiction: Motivation for Participation in Sport and Exercise. J Annett, B Cripps, H. Steinberg, Leicester, UK:, British Psychological Society, pp 1-5.

Wankel, L. M. (1985). Personal and situational factors affecting exercise involvement: The importance of enjoyment. Res Q Exerc Sport, 56, 275-282. https://doi.org/10.1080/02701367.1985.10605374

Willis, J. D., \& Campbell, F. L. (1991). Exercise Psychology. USA, Human Kinetics,

Zırhlığlu, G. (2011). Egzersiz bağımlılı̆̆ının egzersiz davranış parametrelerine göre incelenmesi: van il örneği, e-Journal of New World Sciences Academy.

Zmijewski, C. F., \& Howard, M. O. (2000). Exercise Dependence and Attitudes Toward Eating Among Young Adults. Eating Behaviors, 4, 181-195. https://doi.org/10.1016/S1471-0153(03)00022-9

Zorba, E. (1999). Herkes için Spor ve Fiziksel Uygunluk, 1.Basım, G.S.M. Eğitim Dairesi, Ankara

\section{Copyrights}

Copyright for this article is retained by the author(s), with first publication rights granted to the journal.

This is an open-access article distributed under the terms and conditions of the Creative Commons Attribution license which permits unrestricted use, distribution, and reproduction in any medium, provided the original work is properly cited. 